\title{
Job satisfaction and organizational citizenship behaviour of employees in companies in the Republic of Serbia
}

\author{
Biljana Đorđević
}

Faculty of Economics, University of Niš, Niš, Republic of Serbia

Maja Ivanović-Đukić

Faculty of Economics, University of Niš, Niš, Republic of Serbia

Vinko Lepojević

Faculty of Economics, University of Niš, Niš, Republic of Serbia

Sandra Milanović

Innovation Center, University of Niš, Niš, Republic of Serbia

\begin{abstract}
Organizational citizenship behaviour is a form of employees' behaviour where employees go beyond their formal duties required by job description. Despite the fact that this form of behaviour is not recognized or accepted by the reward system, employees are ready to put in an extra effort in order to achieve organizational goals. However, the readiness of employees to manifest this form of behaviour is not completely unconditional. Numerous empirical studies suggest that such behaviour can be encouraged by employees' job satisfaction, fulfilment of their psychological contract, perception of a high level of organizational justice in the company, support provided to them, etc. Having in mind the importance of this form of employees' behaviour, precisely from the point of view of employers, as well as the factors that influence it, this paper examines the impact of employees' job satisfaction on the level of their organizational citizenship behaviour on the example of the companies in Serbia. The paper starts with three hypotheses. The first and second hypotheses are that employees in companies in Serbia are satisfied with their jobs and that they demonstrate organizational citizenship behaviour. These assumptions were tested using the t-test. The third hypothesis is that employees' satisfaction with their job has a positive effect on their organizational citizenship behaviour. In order to test this hypothesis, methods of correlation and multiple regression analysis were used. The analysis is based on data obtained by primary research realized during 2019. In the research, 244 employees participated. The research showed that there is a positive relationship between respondents' job satisfaction and organizational citizenship behaviour, as well as the positive impact of job satisfaction on organizational citizenship behaviour of employees. This paper's contribution is twofold. First, it provides empirical data regarding the job satisfaction and organizational citizenship behaviour of employees in companies in Serbia. Second, it adds to the existing literature from this field by proposing strategies for increasing the employees' job satisfaction, which will lead to increasing the employees' willingness to manifest organizational citizenship behaviour.
\end{abstract}

\section{Keywords}

job satisfaction, organizational citizenship behaviour, employees, company

\section{Introduction}

Employees have always been an integral part of the work process, but their role and importance have changed over time. During the Industrial Revolution, they were seen only as a supplement to the means of work, while today they become "talent and dream investors" (Bartlett \& Ghoshal, 2002). It is encouraging that today an increasing number of companies recognize the strategic role and importance of employees and see them as a source of competitive advantage. 
A particularly valuable and important category of employees in companies are those employees who possess a high level of expertise, creativity and enthusiasm. Such employees are able to achieve extraordinary results in their work, even if they are not formally required to do so. This form of behaviour is known in the literature as organizational citizenship behaviour.

Research has showed that the manifestation of this form of employees' behaviour has several positive consequences in the working place. It was found that in companies where this form of employees' behaviour is present, the staff turnover rate is low, the company's resources are used rationally and organizational commitment and morale of employees are at a high level (Hemakumara, Khatibi, \& Johar, 2018; Demirel, Elhusadi, \& Alhasadi, 2018; Szabó, Slavić, \& Berber, 2019) etc.

However, the manifestation of this form of employees' behaviour is not completely unconditional. It has been found that the readiness of employees to go beyond their formal duties is influenced by numerous factors. Some of them are fulfilling the psychological contracts of employees (Robinson, 1996; Sadiq, 2014; Milanović, Đokić, \& Đorđević, 2018), perceptions of organizational justice (Niehoff \& Moorman, 1993), perceived organizational support (Miao, 2011; Duffy \& Lilly 2013; Jebeli \& Etebarian, 2015), and many others.

One of the factors that could also be linked to organizational citizenship behaviour is job satisfaction. Previous research has showed that job satisfaction has a positive effect on organizational citizenship behaviour. However, it has also been found that organizational citizenship behaviour has a positive impact on job satisfaction, conversely (Intaraprasong, Dityen, \& Krugkrunjit, 2012; Swaminathan \& Jawahar, 2013) indicating that these phenomenons can reinforce each other.

Having in mind the above stated, the authors of the paper believe that job satisfaction of the employees in Serbian companies have a positive impact on their readiness to exhibit organizational citizenship behaviour. Therefore, the subject of the paper is studying the relationship between these phenomena with the hypothesis that job satisfaction of the employees in Serbian companies has a positive impact on their organizational citizenship behavior. The empirical research included 244 employees. The aim of the paper, is, first to find out the relationship between these job-related variables and second, to propose mechanisms and measures for increasing the employees' job satisfaction.

The paper is structured as follows. First, reviewing the literature on the concepts of job satisfaction and organizational citizenship behaviour is given. Second, hypotheses are developed and the research methodology is explained. Third, the obtained results are presented and discussed. Finally, at the end of the paper, an overview of the study's implications for human resource management and concluding considerations are presented.

\section{Literature review}

\subsection{Job satisfaction}

Job satisfaction is one of the most studied, but also one of the most controversial topics in human resource management (Givaki, Davoudi, Manzari, $\&$ Alipour Katigarie, 2017). The reason for that is that there is still no unique opinion on whether a satisfied worker is necessarily a productive worker. This further suggests that there are still reasons for new research in this area.

When it comes to defining this phenomenon, the time range of research on this topic, as well as the interest of many authors in it, have resulted in numerous explanations of what job satisfaction means. In the literature, however, the opinions of the most referenced authors in this field stand out. Thus, for example, Locke (1976) states that job satisfaction is a pleasant or positive emotional state that results from the evaluation of a job or the experience associated with it. Spector (1997), further, states that job satisfaction can be viewed either as a global feeling arising from doing a particular job or as a constellation of different attitudes about different aspects of work.

Mullins (2005) supports the view that job satisfaction is a multidimensional phenomenon that has different meanings for different people (Mullins, 2005 in Aziri, 2011; Ivanović-Đukić, Đorđević, \& Lepojević, 2018), suggesting that what particular employee may be satisfied with is not necessarily the source of job satisfaction of other employees. This can be explained by the fact that different people have different needs and expectations from the job. In that sense, Adenuga (2015) states that job satisfaction reflects the level of compatibility between employees' expectations of the job and the rewards that the job provides.

It can be concluded from the above definitions of job satisfaction that the causes of job 
satisfaction or dissatisfaction can be based on different grounds for different people.

An important topic regarding job satisfaction in the literature was investigating the causes of this phenomenon as well. Summarizing all the potential causes of this phenomenon, Riaz (2016) states that there are five dominant models of job satisfaction. Those models are: the model of the fulfilment of needs, the model of discrepancy in the level of realized expectations, the model of values, the model of equity and the model of genetic predisposition (Riaz, 2016). The essence of the needs-fulfilment model is that employees will be satisfied with the job to the extent that the job enables them to satisfy their needs. The model of discrepancy in the level of realized expectations is based on the premise that employees will be satisfied with the job if their expectations of the job are met, or if there is no mismatch in this regard. The value model is based on the belief that employees will be satisfied with the job if it allows them to achieve values that are important to them. The equity model is based on the attitude that employees will be satisfied with their job if they believe that the rewards in the company are fair, meaning that equal results are followed by equal rewards. Finally, the model of genetic predisposition is based on the belief that job satisfaction is partly a function of personal traits and genetic factors. In other words, this model is based on the attitude that stable individual differences are important in explaining differences in job satisfaction.

Despite the conceptual differences related to explaining the causes of job satisfaction, the authors agree that this phenomenon is related to many important phenomena in the working environment. In this regard, it was found that job satisfaction has a negative impact on the intention to leave the company (Wang \& Zhang, 2010), positive effect on the quality of services provided to clients (Singh \& Jain, 2013), positive effect on the commitment to the goals of the company (Kuzey, 2012; Latif, Ahmad, Qasim, Mushtaq, Ferdoos, \& Naeem, 2013), etc.

One of the phenomena that job satisfaction is also associated with is the organizational citizenship behaviour of employees.

\subsection{Organizational citizenship behaviour}

The founder of the concept of organizational citizenship behaviour is Organ (1988). This author sees in organizational citizenship behaviour of employees a behaviour that is discretionary (voluntary) but which contributes to the more effective functioning of the organization, even though it is not directly and explicitly recognized by the reward system in the company. Because this form of employees' behaviour is not formally required of them, it is often referred to as behaviour that exceeds the role assigned to employees in the organization (Bienstock, DeMoranville, \& Smith, 2003).

In the literature, it is almost common to look at the concept of organizational citizenship behaviour through its five dimensions: conscientiousness, altruism, civic virtues, sportsmanship, or "fair play", as well as courtesy. According to Organ (1988), conscientiousness reflects discretionary behaviour that is above the minimum required behaviour of the employee. Altruism refers to helping other team members in facing various organizational problems or tasks. Civic virtues reflect behaviour that demonstrates a willingness to participate responsibly in the life of the organization. Sportsmanship or "fair play" behaviour refers to the tolerance of employees towards others, as well as the willingness to accept changes in the organization even if they do not agree with them. Finally, courtesy reflects the care of employees for others or a willingness to help others (Organ, 1988).

Podsakoff, MacKenzie, Paine, and Bachrach (2000) have a very analytical approach when it comes to forms of organizational citizenship behaviour. Namely, they distinguish seven forms of this behaviour, such as assistance, "fair play" or sportsmanship, innovation, civic virtues, organizational commitment, self-satisfaction and individual growth.

Anderson and Gerbing (1988) stressed that the concept of organizational citizenship behaviour can be viewed as stratified, pointing out that organizational citizenship behaviour can be observed from two perspectives. Thus, they make a distinction between citizenship behaviour of employees that is directed towards individuals (organizational citizenship behaviour - individual) and citizenship behaviour that is directed towards the organization (organizational citizenship behaviour - organizational).

Since this concept, like the previous one, constantly attracts the attention of theorists, the views of its essence can also be found in more recent papers. Thus, Zeyada (2018) explains organizational citizenship behaviour as optional and voluntary employee's behaviour. Thiruvenkadam et al. (2017), further, state that 
this form of behaviour does not have necessarily to be manifest by employees who achieve superior performance. For this form of behaviour to be demonstrate it is necessary that employees are ready to go "a step further", concerning what is formally required of them. In other words, this form of behaviour is characteristic of employees who are willing to invest more effort than the minimum that requires the satisfactory performance of their work (Thiruvenkadam, Yabesh, \& Durairaj, 2017).

Organizational citizenship behaviour as the previously described phenomenon (job satisfaction), has also a significant impact in working place. For example, it was found that this form of behaviour has a positive impact on performance at the organizational level (Podsakoff et al., 2000). Some recent studies found that this form of employees' behaviour is negatively correlated with staff turnover, but, on the other side, has a positive impact on the rational use of the company's resources, organizational commitment, employees' morale, and overall organizational goals (Hemakumara et al., 2018; Demirel et al., 2018).

\subsection{Hypothesis development}

The relationship between phenomena such as job satisfaction and organizational citizenship behaviour has been researched by a vast number of authors. Consequently, there are a large number of empirical studies regarding this topic. In almost all of them it was found that there is a relationship between these phenomena, but in terms of the direction of influence, a unique conclusion cannot be given (Podsakoff, MacKenzie, \& Hui, 1993). Namely, in some studies, it has been found that job satisfaction leads to the manifestation of organizational citizenship behaviour, and in others that job satisfaction results from organizational citizenship behaviour (Koys, 2001).

However, it seems that more studies have found that job satisfaction of employees leads to their exhibition of organizational citizenship behaviour. For example, it was found that job satisfaction and affective commitment of employees have a positive impact on organizational citizenship behaviour (Uludağ, Khan, \& Güden, 2011). In some studies, for example, it was found that intrinsic and extrinsic factors of job satisfaction are good predictors of organizational citizenship behaviour (Mohammad, Habib, \& Alias, 2011). A study by Huang, You and Tsai (2012) also found that peer satisfaction, as one aspect of job satisfaction, affects organizational citizenship behaviour significantly. The positive impact of job satisfaction on organizational citizenship behaviour has been found in many other studies as well (Schappe, 1998; Intaraprasong et al., 2012; Arif \& Chohan, 2012; Günay, 2018).

Bearing in mind the above, the authors of the paper believe that situation regarding the relationship between employees' job satisfaction and organizational citizenship behaviour in the companies in Serbia is not different than in other countries, so the hypotheses that are going to be tested in this paper are as follows:

$\mathrm{H1}$ : Employees in companies in Serbia are satisfied with their jobs.

$\mathrm{H} 2$ : Employees in companies in Serbia show organizational citizenship behaviour.

H3: Employees' satisfaction with aspects of their job in companies in Serbia has a positive effect on their organizational citizenship behaviour.

\section{Research methodology}

Procedure. These hypotheses were tested based on data from a sample of employees in Serbia. Employees were surveyed during 2019 in order to determine the level of their job satisfaction and organizational citizenship behaviour. 300 questionnaires were distributed to employees who agreed to participate in the survey. 244 employees completed it, giving a response rate of 81.33 per cent. There were no incomplete questionnaires, so all of them were included in the analysis. Students of the Faculty of Economics, University of Niš, who performed professional practice within regular student activities, distributed the questionnaires to employees. Employees from 33 companies participated in the research. Their structure is as follows: 14 micro, 10 small, 5 medium and 4 large companies. Regarding the activities of the companies whose employees were included in the research, a wide range thereof was determined.

Sample. Among the respondents, 45.9 per cent were men, while the percentage of women was 54.1. This indicates approximately equal participation of men and women. According to the age criterion, respondents under the age of 25 amounted to 9 per cent of the sample. The largest part, 47.1 per cent, were respondents of the ages between 26 and 40. Respondents of the ages between 41 and 55 amounted to 38.1 per cent, while 5.7 per cent were those with ages over 55 . 
When it comes to educational structure, the respondents predominantly had the fourth level of education, i.e., completed secondary school $(36.1 \%)$ and the sixth level of education, i.e., completed college/university $(27.0 \%)$ (Table 1$)$.

Instruments. The first part of the questionnaire was designed to examine the demographic characteristics of respondents, while the second part of the questionnaire contained questions that sought to determine the level of their job satisfaction and organizational citizenship behaviour. Job satisfaction was measured by means of seven questions, where the respondents rated the degree of agreement with the listed statements on a five-point Likert scale from 1 - I completely disagree to 5 - I completely agree. The questionnaire used to measure job satisfaction was created by Fernandes and Awamleh (2006) in the expatriate job satisfaction survey, and was later used in many other studies. Each statement in the questionnaire represents one segment of the overall job satisfaction of the employee. An example of a job satisfaction statement is: "My opinion is respected at work." The reliability of the measuring scale expressed by the Cronbach's alpha indicator in the value of 0.864 was obtained by excluding the statement from the analysis: "In principle, I am satisfied/with this job."

Organizational citizenship behaviour was measured through eight questions using a fivepoint Likert scale, where 1 represented complete disagreement with the statement and 5 complete agreements with the statement. The questionnaire used in the survey was previously introduced by Sanders and Roefs (2002). An example of a statement for measuring organizational citizenship behaviour is: "Even when no one asks me, I try to help others not to make a mistake." The reliability of the measuring scale expressed by the Cronbach's alpha indicator in the value of 0.835 was obtained by excluding the statement from the analysis: "Regardless of changes in work, I will always try to do my job as well as possible."

Cronbach's alpha coefficients, as the most commonly used measure of scale reliability, show acceptable reliability (Field, 2018) and are comparable to the original measurement scales used in similar studies (Sanders \& Roefs, 2002; Fernandes \& Awamleh, 2006).

Data analysis. IBM SPSS program, version 26 was used for the analysis of the obtained data. First, the testing of data deviation from normality was performed. To test the proposed hypothesis, ttest, Pearson correlation and multiple linear regression were applied.

Table 1 Sample structure

\begin{tabular}{l|c|c}
\hline & Frequency & Percentage (\%) \\
\hline Gender & $\mathbf{2 4 4}$ & $\mathbf{1 0 0}$ \\
\hline Male & 112 & 45.9 \\
\hline Female & 132 & 54.1 \\
\hline Age & $\mathbf{2 4 4}$ & $\mathbf{1 0 0}$ \\
\hline Up to 25 years & 22 & 9.0 \\
\hline 26-40 years & 115 & 47.1 \\
\hline 41-55 years & 93 & 38.1 \\
\hline Over 55 years & 14 & 5.7 \\
\hline Education (level) & $\mathbf{2 4 4}$ & $\mathbf{1 0 0}$ \\
\hline II & 1 & 0.4 \\
\hline III & 16 & 6.6 \\
\hline IV & 88 & 36.1 \\
\hline V & 30 & 12.3 \\
\hline VI & 66 & 27.0 \\
\hline VII & 33 & 13.5 \\
\hline VIII & 10 & 4.1 \\
\hline & Source: the authors' calculation
\end{tabular}

According to Cohen (1992), if the Pearson correlation coefficient has a value of \pm 0.10 , it will represent a small effect, \pm 0.30 a medium effect, and \pm 0.50 a large effect. A threshold of $p$ $<0.05$ was taken for the level of statistical significance of the results.

Table 2 Minimum, maximum, mean and correlation between variables

\begin{tabular}{l|l|l|l|l|l|l|l|l|l|l}
\hline Variable & Mean & $\begin{array}{l}\text { St. } \\
\text { Dev. }\end{array}$ & JS1 & JS2 & JS3 & JS4 & JS5 & JS6 & JS & OCB \\
\hline My opinion is respected at work (JS1) & 3,8852 &, 84324 & 1 & & & & & & & \\
\hline $\begin{array}{l}\text { Most people in this company are satisfied with } \\
\text { their job (JS2) }\end{array}$ & 3,6557 & 1,10569 &, $333^{* *}$ & 1 & & & & & & \\
\hline $\begin{array}{l}\text { I am satisfied with the recognition I receive for } \\
\text { the job (JS3) }\end{array}$ & 3,7910 &, 98620 &, $456^{* *}$ &, $587^{* *}$ & 1 & & & & & \\
\hline $\begin{array}{l}\text { I am satisfied with my earnings having in mind } \\
\text { the earnings for similar jobs in other companies } \\
\text { (JS4) }\end{array}$ & 3,7090 & 1,11912 &, $449^{* *}$ &, $451^{* *}$ &, $590^{* *}$ & 1 & & & & \\
\hline $\begin{array}{l}\text { I am satisfied with the relationship between my } \\
\text { boss and other employees (JS5) }\end{array}$ & 3,9385 & 1,09258 &, $394^{* *}$ &, $541^{* * *}$ &, $546^{* *}$ &, $456^{* *}$ & 1 & & & \\
\hline $\begin{array}{l}\text { I am satisfied with the way my boss directs and } \\
\text { organizes employees (JS6) }\end{array}$ & 3,9918 & 1,11846 &, $462^{* *}$ &, $567^{* *}$ &, $521^{* *}$ &, $527^{* *}$ &, $808^{* *}$ & 1 & & \\
\hline
\end{tabular}




\begin{tabular}{l|l|l|l|l|l|l|l|l|l|l}
\hline Job Satisfaction (JS) & 3,8286 &, 80910 &, $641^{* *}$ &, $761^{* *}$ &, $795^{\star *}$ &, $755^{\star *}$ &, $819^{* *}$ &, $849^{* *}$ & $(, 864)$ & \\
\hline Organizational Citizenship Behaviour (OCB) & 3,8343 &, 76525 &, $441^{* *}$ &, $367^{* *}$ &, $399^{\star *}$ &, $402^{* *}$ &, $370^{* *}$ &, $347^{* *}$ &, $497^{* *}$ & $(, 835)$ \\
\hline
\end{tabular}

Note: ${ }^{* *}$ Correlation is significant at 0.01 level; the values of the Cronbach's alpha coefficient are presented in parentheses

Source: the authors' calculation

\section{Results, analysis and discussion}

Table 2 shows the mean, standard deviation and correlation coefficients between all variables that are the subject of analysis. The mean value of the variables job satisfaction and organizational citizenship behaviour is higher than 3 on the Likert scale from 1 to 5, which suggests that employees in Serbia are satisfied with the work they do and that they manifest organizational citizenship behaviour. A value of 3 is taken as the reference value since on the Likert scale it denotes a neutral attitude. All values less than 3 indicate a negative attitude towards job satisfaction and organizational citizenship behaviour, while values above 3 indicate a positive attitude towards the same phenomena.

Based on the data from Table 2, it can be concluded that the mean values of all responses that contribute to the overall job satisfaction are higher than three. The data also show that employees are the most satisfied with the relationship with the superiors (Mean $=3.9385$, St.dev. $=1.09258)$ and their leadership style $($ Mean $=3.9918$, St.dev. $=1.11846)$. The data from Table 2 further show that employees are the least satisfied with the earnings they receive in their company (Mean $=3.7090$, St.dev. = 1.11912). Finally, Table 2 shows that the overall job satisfaction of employees in Serbia has an average value above 3, i.e., to be 3.8286 (St.dev. $=0.80910)$, indicating that employees are generally satisfied with the work they do.

When it comes to organizational citizenship behaviour, the data indicate that employees in companies in Serbia manifest this form of behaviour, bearing in mind that the average value of this variable is above 3 (Mean $=3.8342$, St.dev. $=0.76525)$.

An important data from Table 2 is that the correlation coefficient is 0.497 , which shows that there is a positive relationship between employee job satisfaction and organizational citizenship behaviour with a medium practical effect (Cohen, 1992).

In order to test the first and second hypotheses that employees in Serbia are satisfied with their jobs and manifest organizational citizenship behaviour, the t-test was applied (Table 3).

Table 3 T-test

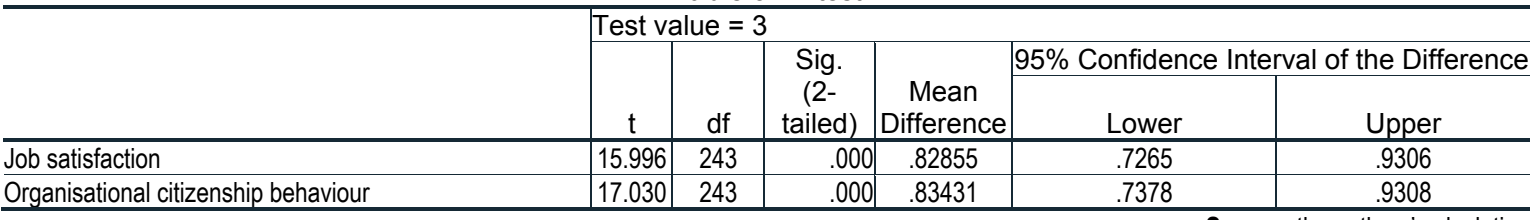

Source: the authors' calculation

The data in Table 3 present that the attitudes of the surveyed employees differ statistically significantly from the value 3 , which, according to the used Likert scale, means a neutral attitude towards job satisfaction and organizational citizenship behaviour. In addition, the data show that respondents are satisfied with the work they do $(t=15.996, d f=243, p=0.000)$ and that they demonstrate organizational citizenship behavior at work $(\mathrm{t}=17.030, \mathrm{df}=243, \mathrm{p}=0.000)$. Based on the above, it can be concluded that hypotheses $\mathrm{H} 1$ and $\mathrm{H} 2$ have been confirmed.

Hypothesis 3 that satisfaction with job aspects of employees in companies in the Republic of Serbia has a positive effect on their organizational citizenship behaviour was tested by using multiple linear regression analysis, and the results are shown in Table 4.

Table 4 Multiple linear regression analysis

\begin{tabular}{l|r}
\hline Dependent variable & $\begin{array}{c}\text { Organizational } \\
\text { citizenship behaviour }\end{array}$ \\
\hline Constant & 1.752 \\
\hline JS1 - My opinion is respected at work & $.254^{\star \star \star}$ \\
\hline JS2 - Most people in this company are satisfied with their job & .096 \\
\hline JS3 - I am satisfied with the recognition I receive for the job & .049 \\
\hline
\end{tabular}




\begin{tabular}{l|r}
\hline JS4 - I am satisfied with my earnings having in mind the earnings for similar jobs in other companies & $.109^{*}$ \\
\hline JS5 - I am satisfied with the relationship between my boss and other employees & .118 \\
\hline JS6 - I am satisfied with the way my boss directs and organizes employees & -.078 \\
\hline R square & .286 \\
\hline Adjusted R2 & .268 \\
\hline Change R2 & $.286^{* * *}$ \\
\hline F & $15.853^{* * *}$ \\
\hline & Note: ${ }^{* * *} p<0.001,{ }^{*} p<0.05$
\end{tabular}

Source: the authors' calculation

The data listed in Table 4 indicate the existence of the impact of satisfaction with different aspects of the job on the organizational citizenship behaviour of employees in the Republic of Serbia (adjusted R2 $=.268, \mathrm{~F}=$ $15.853, \mathrm{p}<0.05)$, which indicates that hypothesis H3 was confirmed. Multiple linear regression analysis also shows that respondents' satisfaction with certain aspects of work explains $28.6 \%$ of the variability of their organizational citizenship behaviour. Given that the model is statistically significant $(\mathrm{F}(6.237)=15.853, \mathrm{p}<0.05)$, it can be used to estimate the influence of independents on the dependent variable, and the regression equation has the following form:

Organizational Citizenship Behavior $=1.752+$ $0.254(\mathrm{JS} 1)+0.096(\mathrm{JS} 2)+0.049(\mathrm{JS} 3)+0.109$ $($ JS4) $+0.118($ JS5) $-0.078($ JS6)

Non-standardized beta coefficients suggest that the influence of the first five independent variables is positive, while the sixth variable has a negative impact on the dependent variable organizational citizenship behaviour. In addition, when employees' satisfaction with some aspect of job satisfaction increases, they are more likely to exhibit organizational citizenship behaviour and vice versa for the latter variable. However, in the mentioned regression equation, only in the first and fourth dimensions of job satisfaction, a statistically significant influence on organizational citizenship behaviour was detected, because only their regression coefficients were significant at the level of $p<0.05$. Therefore, satisfaction with respect for the employee's opinion and earnings are the main factors of job satisfaction that have an impact on the organizational citizenship behaviour of the employee. In addition, a higher regression coefficient in terms of satisfaction with respecting the employees' opinion indicates a stronger influence of this variable on organizational citizenship behaviour than the variable satisfaction with employee earnings.
The results of the study conducted by the authors of this paper are similar to the results found in other studies. Namely, a study conducted by Ilies, Lanajb, Pluutc and Gohd (2018) among employees in local government and one university showed that job satisfaction was a mediatory variable in the relationship between the fulfilment of intrapersonal and interpersonal needs and organizational citizenship behaviour. It was shown that the fulfilment of intrapersonal and interpersonal needs has a direct impact on job satisfaction, and that, then, job satisfaction as a mediator variable has a direct impact on organizational citizenship behaviour. In the research conducted by these authors, it was also found that job satisfaction explains 25 per cent of the variability in organizational citizenship behaviour ( $\beta=0.25, \mathrm{p}=0.008)$, which is in line with the results of our research.

The results of our study are also in line with the results of Shafazawana, Yeh Ying, Zuliawati and Sukumaran (2016) who found a moderate positive correlation between job satisfaction and organizational citizenship behaviour $(r=0.451, p$ $<0.01)$. Linear regression analysis showed through the coefficient of determination that $26.9 \%$ of the variability in organizational citizenship behaviour of teachers in secondary schools can be explained by job satisfaction and organizational commitment. In the same study, it was found that job satisfaction had a statistically significant effect on organizational citizenship behaviour $(\beta=0.299, \mathrm{p}<0.01)$ (Shafazawana et al., 2016, p. 609).

Finally, Huang et al. (2012) investigated the impact of organizational climate, job satisfaction dimensions, and organizational commitment on three dimensions of organizational citizenship behaviour among nurses. Their results suggest that only the satisfaction with colleagues, as one of the five researched dimensions of job satisfaction, significantly affects the dimension of organizational citizenship behaviour, while in our research satisfaction with respect paid to employees' opinion and earnings are the main 
factors influencing organizational citizenship behaviour.

\section{Implications for human resource management}

Since numerous empirical studies cited in the paper have shown that both job satisfaction and organizational citizenship behaviour of employees can be linked to several positive phenomena in the work environment, companies should take all measures in the field of human resource management to make a positive impact on both phenomena. At the same time, having in mind the nature of their relations, it can be expected that these phenomena will also have a positive influence on each other.

In the context of the empirical research conducted by the authors of this paper, as well as the proven hypotheses, there are several recommendations for managers in companies in the Republic of Serbia in order to increase employees' job satisfaction.

The first recommendation is related to the improvement of the reward system, which is a very powerful mechanism for increasing employee's job satisfaction (Tănăsescu \& Leon, 2019). Namely, although the research showed that employees who were included in the survey are generally satisfied with their jobs, there is a place for increasing it through increasing the satisfaction with the rewarding system. Namely, in the study, it was found that the lowest average satisfaction ratings are expressed in this area. The survey showed that when it is about satisfaction with the recognition that employees receive for their work the average grade is 3.79 , while when it comes to satisfaction with earnings compared to similar companies, the average grade of satisfaction is 3.70 . Having in mind the previously stated, employees' job satisfaction can be increased by greater use of intangible forms of rewards (praise, recognition, etc.), as well as by striving to establish the highest possible level of external justice when it comes to paying. Otherwise, those employees who think they are worth more may leave companies.

However, organizational citizenship behaviour can be encouraged by mechanisms and measures other than those described above. Taking into consideration that the aforementioned studies have shown that this form of behaviour is influenced by the fulfilment of a psychological contract, the perception of organizational justice, as well as organizational support, therefore very useful mechanisms for stimulating organizational citizenship behaviour can be found in these areas. Thus, when it comes to a psychological contract, the employer must fulfil the given promises, because employees will be more satisfied with the relationship with him and more willing to engage in their workplace (Coyle-Shapiro \& Kessler, 2000). Conversely, if employees feel that their expectations have been betrayed, that is, that the employer has not fulfilled the given promises, they will reduce their efforts only to the level defined by their role in the organization or will even reduce it below that level.

The organizational support that employees receive can also encourage them to go beyond their formal duties. Specifically, if employees believe that the organization values them and supports them, according to the theory of social exchange, it can be expected that employees will "reciprocate" by engaging in the execution of work tasks more than what is expected of them. In other words, perceived organizational support will lead to reciprocal additional engagement by employees where they will try to reciprocate with better performance in order to "repay" for the awards and support received. Such messages that the theory of social exchange sends have been confirmed in numerous empirical studies (Chiang \& Hsieh, 2012; Cheung, 2013; Jovanović, 2019).

Finally, the space for stimulating employees to express the organizational citizenship behaviour to a greater extent is in the domain of organizational justice. This is because numerous studies have confirmed the positive link between the perception of justice in the organization and certain dimensions of organizational citizenship behaviour. Thus, Konovsky and Folger (1991) established a strong link between procedural fairness and employee's altruism. Based on the findings of their study, it can be concluded that if employees are satisfied with the decision-making process in the organization (and this is most often when they are involved in their decision-making), they are more willing to help other members of the organization when they face difficulties. The positive impact of organizational justice on organizational citizenship behaviour has been confirmed in several other studies (Karriker \& Williams, 2009; Jafari \& Bidarian, 2012).

\section{Conclusion}

The subject of the authors' research were employees in 33 companies operating in the 
territory of Serbia. A total of 244 surveyed employees expressed the view that they were satisfied with the work they were doing and that they showed organizational citizenship behaviour. The analysis further showed that there is a positive relationship between respondents' job satisfaction and their organizational citizenship behaviour, but also the positive impact of job satisfaction on organizational citizenship behaviour. In addition, the research showed that $28.6 \%$ of the variability of the dependent variable could be explained by the variability of the independent variable, which in this case is job satisfaction, specifically its aspects. Also, respect for the employee's opinion and satisfaction with earnings are decisive factors for the manifestation of organizational citizenship behaviour of employees. The results of this research are consistent with the results of other studies in this field (Huang et al., 2012; Shafazawana et al., 2016; Ilies et al., 2018) so that the reliability of the results of the presented analysis is correct.

Following the obtained research results, the paper proposes certain mechanisms and measures that human resources managers can use to encourage employees in companies in Serbia to manifest organizational citizenship behaviour, whether they act directly on this form of behaviour, or by increasing job satisfaction.

However, this paper is not without limitations. They are primarily related to the size of the sample, as well as the fact that only employees in one part of Serbia were surveyed, mostly in the south-eastern part. Therefore, for the conclusions to be generalized, future research on this topic must be followed by an increase in the number of respondents. However, despite the obvious limitations of this research, it has some contributions. First, it provides empirical data on job satisfaction and organizational citizenship behaviour of employees in Serbia (the empirical studies in this area are quite rare). Second, it proposes set of measures to encourage organizational citizenship behaviour through increasing the employees' job satisfaction, which will simultaneously contribute to improvement of working conditions for employees.sm

\section{References}

Adenuga, O. A. (2015). Impact of occupational stress on job satisfaction and mental health of first bank employees: implication for personnel psychologists. Science, 1(1), 15-21.

Anderson, J.C., \& Gerbing, D.W. (1988). Structural equation modeling in practice: A review and recommended two step approach. Psychological Bulletin, 103(3), 411- 423. https://doi.org/10.1037/0033-2909.103.3.411

Arif, A., \& Chohan, A. (2012). Job satisfaction is influencing the organizational citizenship behaviour: A study on employees working in banking sector of Pakistan. Interdisciplinary Journal of Contemporary Research in Business, 4(8), 74-88.

Aziri, B. (2011). Job Satisfaction: A Literature Review. Management Research and Practice, 3(4), 77-86.

Bartlett, A. Ch., Ghoshal, S. (2002). Building Competitive Advantage Through People, MIT Sloan Management Rewiew, 43(2), 34-41.

Bienstock, C. C., DeMoranville, C. W., \& Smith, R. K. (2003). Organizational citizenship behavior and service quality. Journal of Services Marketing, 17 (4/5), 357377. https://doi.org/10.1108/08876040310482775

Cheung, M. F. (2013). The mediating role of perceived organizational support in the effects of interpersonal and informational justice on organizational citizenship behaviors. Leadership \& Organization Development Journal, 34(6), 551-572.

https://doi.org/10.1108/LODJ-11-2011-0114

Chiang, C. F. \& Hsieh, T. S. (2012). The impacts of perceived organizational support and psychological empowerment on job performance: The mediating effects of organizational citizenship behavior. International Journal of Hospitality Management, 31(1), 180-190.

https://doi.org/10.1016/j.ijhm.2011.04.011

Cohen, J. (1992). Quantitative methods in psychology: A power primer. Psychological Bulletin, 112(1), 153-159. https://doi.org/10.1037/0033-2909.112.1.155

Coyle-Shapiro, J., \& Kessler, I. (2000). Consequences of the psychological contract for the employment relationship: A large scale survey. Journal of Management Studies, 37(7), 903-930. https://doi.org/10.1111/1467-6486.00210

Demirel, Y., Elhusadi, I., \& Alhasadi, A. (2018). The relationship between organizational citizenship behavior and organizational factors. International Journal of Business and Management Invention (IJBMI), 7(3), 2739.

Duffy, J. A., \& Lilly J. (2013). Do individual needs moderate the relationships between organizational citizenship behavior, organizational trust and perceived organizational support? Journal of Behavioral \& Applied Management, 14(3),185-197. https://doi.org/10.21818/001c. 17930

Fernandes, C., \& Awamleh, R. (2006). Impact of organizational justice in an expatriate work environment. Management Research News, 29(11), 701-712. https://doi.org/10.1108/01409170610716016

Field, A. (2018). Discovering Statistics Using IBM SPSS Statistics (5th ed.). London: SAGE Publications Ltd.

Givaki, E., Davoudi, H., Manzari, A. R., \& Alipour Katigarie, S. (2018). Job satisfaction prediction based on job motivation and emotional intelligence of managers and employees. Iranian journal of educational sociology, 1(7), 112-118.

Hemakumara, G., Khatibi, A., \& Johar, G. (2018). Job satisfaction and organizational citizenship behavior among the administrative staff of state universities in Sri Lanka. International Journal of Management Sciences and Business Research, 7 (8), 40-44. https://doi.org/10.1016/j.ijhm.2011.04.011 
Huang, C.C., You, C.S., \& Tsai, M.T. (2012) A multidimensional analysis of ethical climate, job satisfaction, organizational commitment, and organizational citizenship behaviors. Nursing Ethics, 19(4) 513-529.

https://doi.org/10.1177/0969733011433923

Ilies, R., Lanaj, K., Pluut, H., \& Goh, Z. (2018). Intrapersonal and interpersonal need fulfillment at work: Differential antecedents and incremental validity in explaining job satisfaction and citizenship behavior. Journal of Vocational Behavior, 108, 151-164. https://doi.org/10.1016/j.jvb.2018.07.005

Intaraprasong, B., Dityen, W., \& Krugkrunjit, P.T. (2012). Job satisfaction and organizational citizenship behavior of personnel at one university hospital in Thailand. The Journal of the Medical Association of Thailand, 95(6). 102-108.

Ivanović-Đukić, M., Đorđević, B., \& Lepojević, V. (2018). Mediating effects of educational level on job related characteristics: Job satisfaction relationship. Strategic Management, 23(2), 13-21. https://doi.org/10.5937/StraMan18020131

Jafari, P., \& Bidarian, S. (2012). The relationship between organizational justice and organizational citizenship behavior. Procedia - Social and Behavioral Sciences 47, 1815-1820. https://doi.org/10.1016/i.sbspro.2012.06.905

Jebeli, M. J., \& Etebarian, A. (2015). Perceived organizational support and organizational citizenship behavior. MAGNT Research Report, 3(4), 153-158.

Jovanović, M. (2019). The political behavior of managers and employers as an instrument for advancing career: Influence and factors on individual and organizational effectiveness. Ekonomika, 65(4), 87-105. https://doi.org/10.5937/ekonomika1904087J

Karriker, J., H., \& Williams, M. L. (2009). Organizational justice and organizational citizenship behavior: a mediated multifoci model. Journal of Management, 35(1), 112-135. https://doi.org/10.1177/0149206307309265

Konovsky, M. A., \& Folger, R. (1991). The effects of procedures, social accounts, and benefits level on victims' layoff reactions. Journal of Applied Social Psychology, 21, 630-650. https://doi.org/10.1111/j.1559-1816.1991.tb00540.x

Koys, D.J. (2001). The effects of employee satisfaction, organizational citizenship behavior, and turnover on organizational effectiveness: a unit-level, longitudinal study. Personnel Psychology, 54, 101-114. https://doi.org/10.1111/j.1744-6570.2001.tb00087.x

Kuzey, C. (2012). Impact of health care employees' job satisfaction on organizational performance support vector machine approach. European Journal of Economic and Political Studies, 5(1), 65-89.

Latif, M. S., Ahmad, M., Qasim, M., Mushtaq, M., Ferdoos, A. \& Naeem, H. (2013). Impact of employee's job satisfaction on organizational performance. European Journal of Business and Management, 5(5), 166-171.

Locke, E.A. (1976) The nature and causes of job satisfaction. Handbook of industrial and organizational psychology, 1, 1297-1343.

Miao, R. T. (2011). Perceived organizational support, job satisfaction, task performance and organizational citizenship behavior in China. Institute of Behavioral and Applied Management, 12 (2), 105-127. https://doi.org/10.21818/001c.17632
Milanović, S., Đokić, M., \& Đorđević, B. (2018). The influence of psychological contract breach on job satisfaction. Facta Universitatis, Series: Economics and Organization, 15(3), 203-215. https://doi.org/10.22190/FUEO1803203M

Mohammad, J., Habib, Q.F., \& Alias, A.M. (2011). Job Satisfaction and organizational citizenship behaviour: an empirical study at higher learning institutions. Asian Academy of Management Journal, 16(2), 149-165.

Mullins, J.L. (2005). Management and organizational behavior, Seventh Edition. Essex: Pearson Education Limited.

Niehoff, P.B., \& Moorman, H. R. (1993). Justice as a mediator of the relationship between methods of monitoring and organizational citizenship behavior. The Academy of Management Journal, 36(3), 527-556. https://doi.org/10.2307/256591

Organ, D. W. (1988). Organizational citizenship behavior: The good soldier syndrome. Lexington, MA: Lexington Books.

Podsakoff, P.M., MacKenzie, S.B., \& Hui, C. (1993). Organizational citizenship behaviors and managerial evaluations of employee performance: a review and suggestions for future research, y Ferris, G.R. (Eds.), Research in Personnel and Human Resources Management, 11 (pp. 1-40). Greenwich, CT: JAI Press.

Podsakoff, P.M., MacKenzie, S.B., Paine, J.B., \& Bachrach, D.G. (2000). Organizational citizenship behavior: A critical review of the theoretical and empirical literature and suggestions for future research. Journal of Management, 26(3), 513-563.

https://doi.org/10.1177/014920630002600306

Riaz, M.N. (2016). What is job-satisfaction? Explain the effects of job-satisfaction on job withdrawal of employees. Retrieved July 25, 2020, from: https://www.researchgate.net/publication/307932016_w hat_is_job-satisfaction_Explain_the_effects_of_jobsatisfaction_on_job_withdrawal_of_employees

Robinson, L. S. (1996). Trust and breach of the psychological contract. Administrative Science Quarterly, 41(4), 574-599. https://doi.org/10.2307/2393868

Sadiq, S. (2014). Relationship between psychological contract violation, supervisory support, psychological contract breach and organizational citizenship behavior. Journal of Business and Management, 16(3), 48-53. https://doi.org/10.9790/487X-16314853

Sanders, K., \& Roefs, A. (2002). Maatschappelijk verantwoord ondernemen en de binding van medewerkers. Gedrag en Organisatie, 15, 94-105.

Schappe, S. P. (1998). The influence of job satisfaction, organizational commitment and fairness perceptions on organizational citizenship behaviour. The Journal of Psychology: Interdisciplinary and Applied, 132 (3), 277290. https://doi.org/10.1080/00223989809599167

Shafazawana, M.T., Yeh Ying, C., Zuliawati, M.S., \& Sukumaran, K. (2016). Managing job attitudes: The roles of job satisfaction and organizational commitment on organizational citizenship behaviors. Procedia Economics and Finance, 35, 604-611. https://doi.org/10.1016/S2212-5671(16)00074-5

Singh, J. K., \& Jain, M. (2013). A Study of employee's job satisfaction and its impact on their performance. Journal of Indian research, 1 (4), 105-111. 
Spector, P. E. (1997). Job Satisfaction: Application, Assessment, Causes, and Consequences. Thousand Oaks: Sage Publications Ltd. https://doi.org/10.4135/9781452231549

Swaminathan, S., \& Jawahar, P. D. (2013). Job satisfaction as a predictor of organizational citizenship behaviour: An empirical study. Global Journal of Business Research, 7 (1), 71-80.

Szabó, S., Slavić, A., \& Berber, N. (2019). Coaching and its effects on individual and organizational performances in Central and Eastern Europe. Anali Ekonomskog fakulteta u Subotici, 55 (41), 67-80. https://doi.org/10.5937/AnEkSub1941067S

Tănăsescu, C. A., \& Leon, R. D. (2019). Human resources practices in the Romanian banking system: Rewards, job satisfaction, and job performance. Management Dynamics in the Knowledge Economy, 7 (4), 469-483. https://doi.org/10.25019/MDKE/7.4.02

Thiruvenkadam, T. Yabesh, I. \& Durairaj, A. (2017). Organizational citizenship behavior: its definitions and dimensions. GE-Journal of Management Research, $5(5), 46-55$.

\section{$\triangle$ Correspondence}

\section{Biljana Đorđević}

University of Niš, Faculty of Economics

Trg kralja Aleksandra Ujedinitelja 11, 18105 Niš, Serbia

E-mail: biljana.djordjevic@eknfak.ni.ac.rs
Uludağ, O., Khan, S., \& Güden, N. (2011). The effects of job satisfaction, organizational commitment, organizational citizenship behavior on turnover intentions. Florida International University Hospitality Review, 29(2), 1-21.

Wang, Z., \& Zhang, L. (2010). An empirical study on relations among person-organization fit, job satisfaction and turnover intention. Chinese Journal Management, 3, 379-385.

Günay, G. Y. (2018). Relationship between job satisfaction, organizational citizenship behavior and employee performance: Sample of Edirne financial office employees in Turkey. American International Journal of Contemporary Research, 8(1), 64-74.

Zeyada, M. (2018). Organizational culture and its impact on organizational citizenship behavior. International Journal of Academic Research in Business and Social Sciences, 8(3), 418-429. https://doi.org/10.6007/IJARBSS/v8-i3/3939 